\title{
Preparation of poly(MPAEMA)/halloysite Nanocomposites Investigation of Antiproliferative Activity
}

\author{
Nevin Çankaya ${ }^{1}$, Serap Yalçın², Nevin Turan ${ }^{3 *}$ \\ ${ }^{1}$ Department of Chemistry, Faculty of Arts and Sciences, Uşak University, 64200 Uşak, Turkey. \\ ${ }^{2}$ Department of Molecular Biology and Genetic, Kırşehir Ahi Evran University, 40100 Kırşehir, Turkey. \\ ${ }^{3}$ Department of Chemistry, Faculty of Arts and Sciences, Muş Alparslan University, 49100 Muş, Turkey.
}

*Corresponding author: Nevin Turan, email: nevintrn@hotmail.com, n.turan@alparslan.edu.tr, phone: $+904362494949-1551$

Received July $8^{\text {th }}, 2020$; Accepted Janaury $2^{\text {nd }}, 2020$.

DOI: http://dx.doi.org/10.29356/jmcs.v65i2.1257

\begin{abstract}
In this present work, the synthesis, characterization, and thermal properties of poly(2-(4methoxyphenylamino)-2-oxoethyl methacrylate) (MPAEMA) polymer/clay-based nanocomposites were investigated by in-situ polymerization. At the characterizations of nanomaterials FTIR, XRD, SEM, and TGA techniques were used. It was determined from XRD and SEM measurements that the morphology of nanocomposites was exfoliated when the clay content in the polymer matrix was kept at 3\% and 5\%. From thermal analysis, a positive correlation was observed between the clay ratio and thermal stability of nanomaterials. Also, the cytotoxic effect of halloysite and its nanocomposites was investigated using XTT assay on HeLa cells. According to the results, nanocomposites showed a non-cytotoxic response and thus they may use safety in many research areas such as medicine, agriculture, cosmetics.
\end{abstract}

Keywords: Polymer/clay nanocomposite; organoclay; thermal stability; in-situ polymerization; HeLa cell line; antiproliferative activity.

Resumen. En este trabajo, se reporta la síntesis, caracterización y propiedades térmicas de nanocompuestos de polímero / arcilla poli(2-(4-metoxifenilamino)-2-oxoetil metacrilato) (MPAEMA), obtenidos mediante polimerización in situ. Para caracterizar los nanomateriales se utilizaron las siguientes técnicas: FTIR, XRD, SEM y TGA. A partir de las mediciones de XRD y SEM se determinó que la morfología de los nanocompuestos muestra exfoliación, cuando el contenido de arcilla en la matriz de polímero se mantiene en 3\% y 5\%. Estudios mediante análisis térmico muestran una correlación positiva entre la relación de arcilla y la estabilidad térmica de los nanomateriales. También se investigó el efecto citotóxico de la halloysita y sus nanocompuestos utilizando el ensayo XTT en células HeLa. Los resultados muestran que los nanocompuestos tienen una respuesta no citotóxica y, por lo tanto, pueden utilizarse con seguridad en muchas áreas de investigación en disciplinas como la medicina, la agricultura y la cosmética.

Palabras clave: Nanocompuesto polímero / arcilla; organoarcilla; estabilidad térmica; polimerización in situ; Línea celular HeLa; actividad antiproliferativa.

\section{Introduction}

Polymer/clay nanocomposites are now an active area of research because of its enhanced physical, mechanical, and chemical properties when compared with those of pure polymer. Polymer/clay nanocomposites comprise dispersions of nanoclay platelets throughout a polymer matrix. Some clay types such as kaolin, 
smectite (montmorillonite), illite, attapulgite, and bentonite are nanofiller used for the preparation of polymer/clay nanocomposites [1-3]. In this present work, raw halloysite clay was used.

Halloysite is a type of clay in the kaolin group shown by the formula $\mathrm{Al}_{2} \mathrm{Si}_{2} \mathrm{O}_{5}(\mathrm{OH})_{4}$. Unlike kaolin, there are water molecules in the structure of halloysite, and while it is morphologically kaolin layered, halloysite is tubular. Halloysite consists of hollow and tubular structures and the inner surface of the tubular structures consists of aluminate and the outer surface consists of silicate structures [4]. Halloysite have been recently used in many different fields due to their unique properties such as their hollow tubular structure, high surface area, surface properties, and high biocompatibility. Halloysite is used as an additive in polymers, as a smart emission system in the pharmaceutical or cosmetic industry, as a soil nourisher in the agricultural industry, and is used to produce transparent porcelain in the ceramic industry [5-10].

Halloysite have multilayer walls with positively charged Al-OH functional groups on the inner surface, and with negatively charged $\mathrm{Si}-\mathrm{OH}$ functional groups on the outer surface [11]. These characteristics make halloysite a great absorbent for both cationic and anionic molecules [5-8]. The advantages of these nanoparticles compared to carbon nanotubes, which have been extensively studied for a wide range of applications, are that halloysite is not toxic for the human body nor hazardous for the environment and have lower manufacturing costs [12]. For these reasons halloysite has been studied for diverse biomedical applications, including inexpensive drug encapsulation, controlled drug delivery [13-15], as a template or nanoreactor for biocatalyst [16], as well as for use in personal care and cosmetics [17].

In this study, raw halloysite clay was used. The aim of this study is to synthesize and characterize polymer/clay nanocomposites, and then to investigate their cytotoxic properties. In the last 50 s, since adding a small amount of clay to the synthesis of the polymer causes changes in the composite (thermal, mechanical, etc.), this method is preferred in new syntheses. Changing the polymer/monomer type or clay type/amount synthesis causes many changes in the composite. In our study, MPAEMA (2-(4-methoxyphenylamino)-2oxoethyl methacrylate) monomer and halloysite clay were preferred for composite synthesis. Our team determined the toxicity value of MPAEMA monomer for HeLa cells as $1.8 \mathrm{mM}$ [18]. In this study, with this idea, MPAEMA polymer/halloysite clay nanocomposites were prepared by in-situ polymerization method, their morphology and thermal properties were discussed, and then its effect on HeLa cancer cell was investigated. HeLa cells are the first cancerous cell line and have many properties like healthy cells. They regulate proteins and genes, can communicate with another cells. HeLa cells have supplied certainly usable biological models for human biology and disease [19]. In addition, the halloysite clay used in the study you are reading has been investigated in different human cells and proved to be non-toxic. In purpose of this study is to produce new non-toxic composite products that can be used in various fields such as medicine and agricultural studies. We have found that poly(MPAEMA)/3\%halloysite, poly(MPAEMA)/5\%halloysite, and poly(MPAEMA) reduce/disappear cell toxicity, and therefore these composites can be widely used in various fields.

\section{Experimental}

\section{Materials}

Natural raw halloysite clay was provided from Esan Eczacıbaşı. XRF (X-Ray Fluorescence) chemical analysis expressed by Esan company: $\mathrm{LOI}$ (Losses of ignition): $16.75 \%, \mathrm{SiO}_{2}: 43.3 \%, \mathrm{Al}_{2} \mathrm{O}_{3}: 38.4 \%, \mathrm{Fe}_{2} \mathrm{O}_{3}$ : $0.8 \%, \mathrm{TiO}_{2}: 0.1 \%, \mathrm{CaO}: 0.08 \%, \mathrm{MgO}: 0.12 \%, \mathrm{Na}_{2} \mathrm{O}: 0.17 \%, \mathrm{~K}_{2} \mathrm{O}: 0.12 \%$. Particle size of halloysite is $<45$ $\mu$, surface area is $128 \mathrm{~m}^{2} / \mathrm{g}$ and the distance between layers is $7 \AA$ (dihydrate) and $10 \AA$ (hydrate). The average nanotube length is 1.2 microns, the average inner tube diameter is $20 \mathrm{~nm}$, and the outer tube diameter is $40 \mathrm{~nm}$. The XRD pattern, SEM and TEM micrographs provided by the Esan of raw halloysite are given Figures 1-3. For MPAEMA monomer synthesis: 4-methoxyaniline, triethylamine, chloroacetyl chloride, and sodium methacrylate (Aldrich). For nanocomposite synthesis: Benzoyl peroxide as initiator; 1,4-dioxane and ethyl alcohol as solvents. 


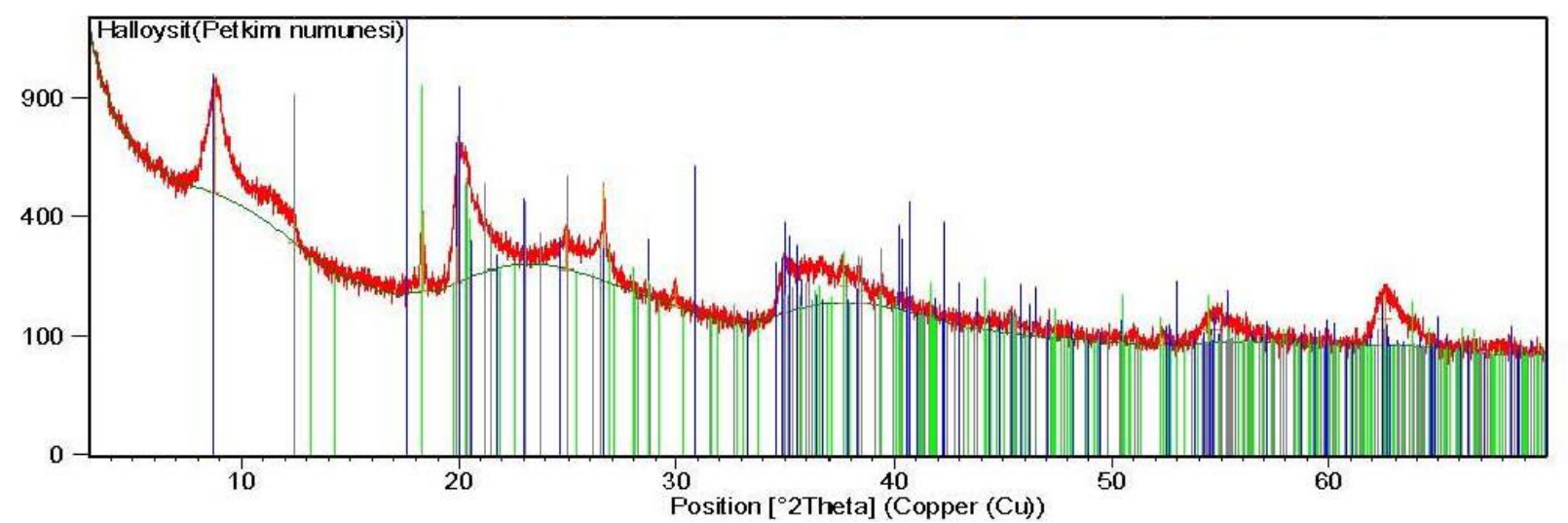

Fig. 1. XRD patterns of the halloysite clay (by Esan).

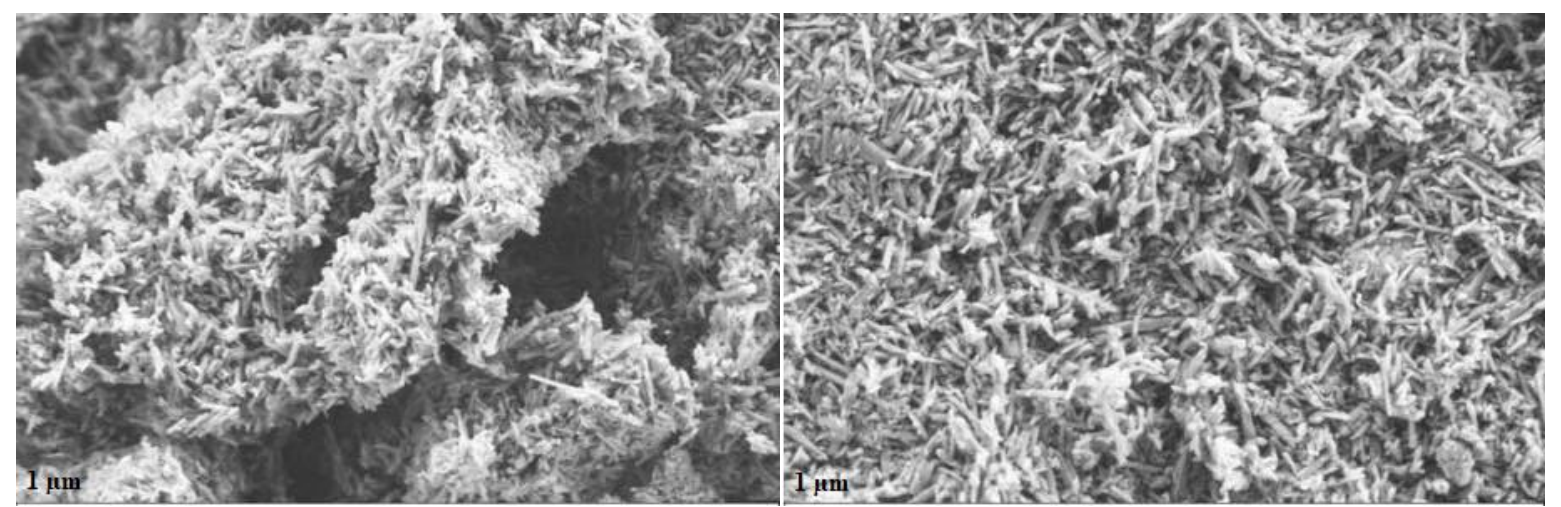

Fig. 2. SEM micrographs of the halloysite clay (by Esan).

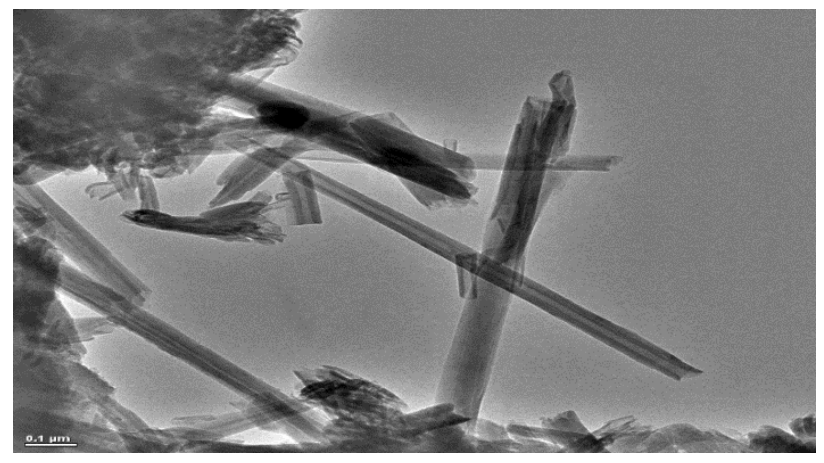




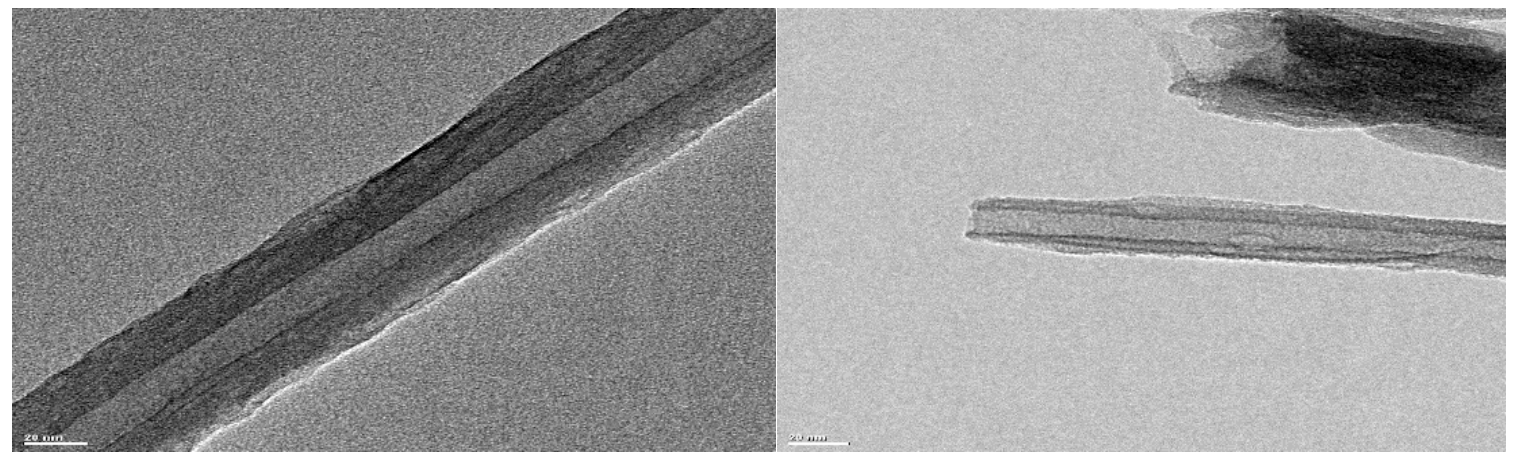

Fig. 3. TEM micrographs of the halloysite clay (by Esan).

\section{Instrumental measurements}

In the characterization of polymers, the Perkin Elmer Spectrum Two (UATR) IR spectrometer in the range of 4000-450 $\mathrm{cm}^{-1}$ for FTIR spectra, Bruker Axs D8 Advance diffractometer with a back monochromator and a $\mathrm{Cu}$ target and $\mathrm{K} \alpha\left(\lambda=1.5418 \mathrm{~nm}\right.$ ) in $2 \theta=10-45^{\circ} \mathrm{C}$ (step of $0.01{ }^{\circ} \mathrm{C}$, at room temperature) for surface morphology images, the Zeiss Evo LS 10 Scanning Electron Microscopy (SEM) at $25 \mathrm{kV}$ for surface morphology images, the Hitachi 7000 TGA/DTA/DTG simultaneous system for thermal analyzes were used heating rate of $10{ }^{\circ} \mathrm{C} \min ^{-1}$ in $\mathrm{N}_{2}$ atmosphere.

\section{Preparation of poly(MPAEMA) and poly(MPAEMA)/organoclay nanocomposites}

MPAEMA monomer was synthesized according to the literature [18,20,23]. MPAEMA was dissolved in $1 \mathrm{~mL}$ 1,4-dioxane and polymerized at $73^{\circ} \mathrm{C}$ with $1 \%$ benzoyl peroxide as free radical initiator. The resulting homopolymer was crystallized with ethyl alcohol (Fig. 4) [20]. Poly(MPAEMA)/halloysite clay nanocomposites were prepared with in-situ method. For this purpose, $1 \mathrm{~g}$ of MPAEMA monomer, and $3 \%$ and $5 \%$ of halloysite clay by mass of the monomer were added to two separate polymerization tube in $2 \mathrm{~mL}$ of $1,4-$ dioxane solvent $[1-3,12]$. These mixtures were mixed with a magnetic stirrer for $24 \mathrm{~h}$ to swell the clay layers with the monomer. Benzoyl peroxide (1\%) was added as the initiator to the mixtures in two different tubes and stirred for $48 \mathrm{~h}$ at $73{ }^{\circ} \mathrm{C}$ by continuously passing through inert argon gas. The synthesized composites were separated from impurities by dissolving in 1,4 dioxane and precipitation in ethyl alcohol ( 3 times), oven dried and sieved through a 20 -micron sieve.

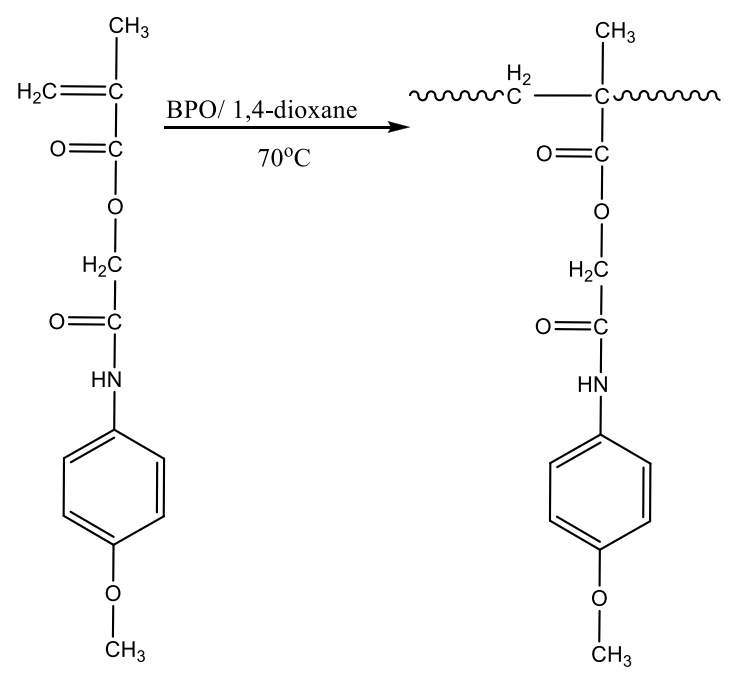

Fig. 4. Synthesis of poly(MPAEMA) homopolymer [20]. 


\section{Antiproliferative effect of halloysite, poly(MPAEMA), and their nanocomposites on HeLa cell line}

HeLa cells (Kırşehir Ahi Evran University, Department of Molecular Biology and Genetics) were cultured in RPMI-1640 supplemented with $10 \%$ (v/v) fetal bovine serum at $37^{\circ} \mathrm{C}$ in a humidified atmosphere containing $5 \% \mathrm{CO}_{2}$. The cells were seeded in 96-well plates (5000 cells/well), and first and second columns of plate were used as medium control and cell. Then, 96 well-plates allowed to attach overnight, and treated with raw halloysite, poly(MPAEMA), and their nanocomposites.

After $48 \mathrm{~h}$, XTT reagent (Biological Industries USA) was added to each well and then absorbance values were read by a micro culture plate reader (BioTEK) at $450 \mathrm{~nm}$. XTT analysis is a colorimetric assay, and the live cells are usually formed an orange formazan product upon the reduction in mitochondria. Conversely, no staining in dead cells. The percentage of the live cells are calculated by formula: $(\%)=[100 \times$ (sample abs) / (control abs)]. In the XTT analysis, our negative control group is blank cells, and the positive control is the cells to which we applied composite. The average dye intensity of the cell control column defined the $100 \%$ cell proliferation.

\section{Results and discussion}

\section{FTIR spectroscopy}

The spectrum of halloysite clay show the characteristic bands at $\sim 3695 \mathrm{~cm}^{-1}$ represents to the stretching vibration of the inner surface $\mathrm{OH}$ groups, while the band at $\sim 3622 \mathrm{~cm}^{-1}$ represents to the stretching band of the inner groups [24,25]. The most characteristic bands observed for nanocomposites are seen in $\left(\mathrm{cm}^{-1}\right) 3309(\mathrm{~N}-$ H), 2941 (aliphatic C-H), 1734-1737 (C=O ester stretch), 1670-1675 (C=O amide stretch), 1607 (C=C stretch on aromatic ring), 1234-1238 and 1509-1512 (symmetrical and asymmetrical C-O-C) [20, 21]. The peaks observed in the homopolymer are also seen in nanocomposites. On the other hand, Al-O and Si-O stretching bands, which are characterized for clay, can be observed in nanocomposites [1-3,21,24,26]. Fig. 5 shows FTIR spectra of poly(MPAEMA)/3\% halloysite and poly(MPAEMA)/5\% halloysite nanocomposites.

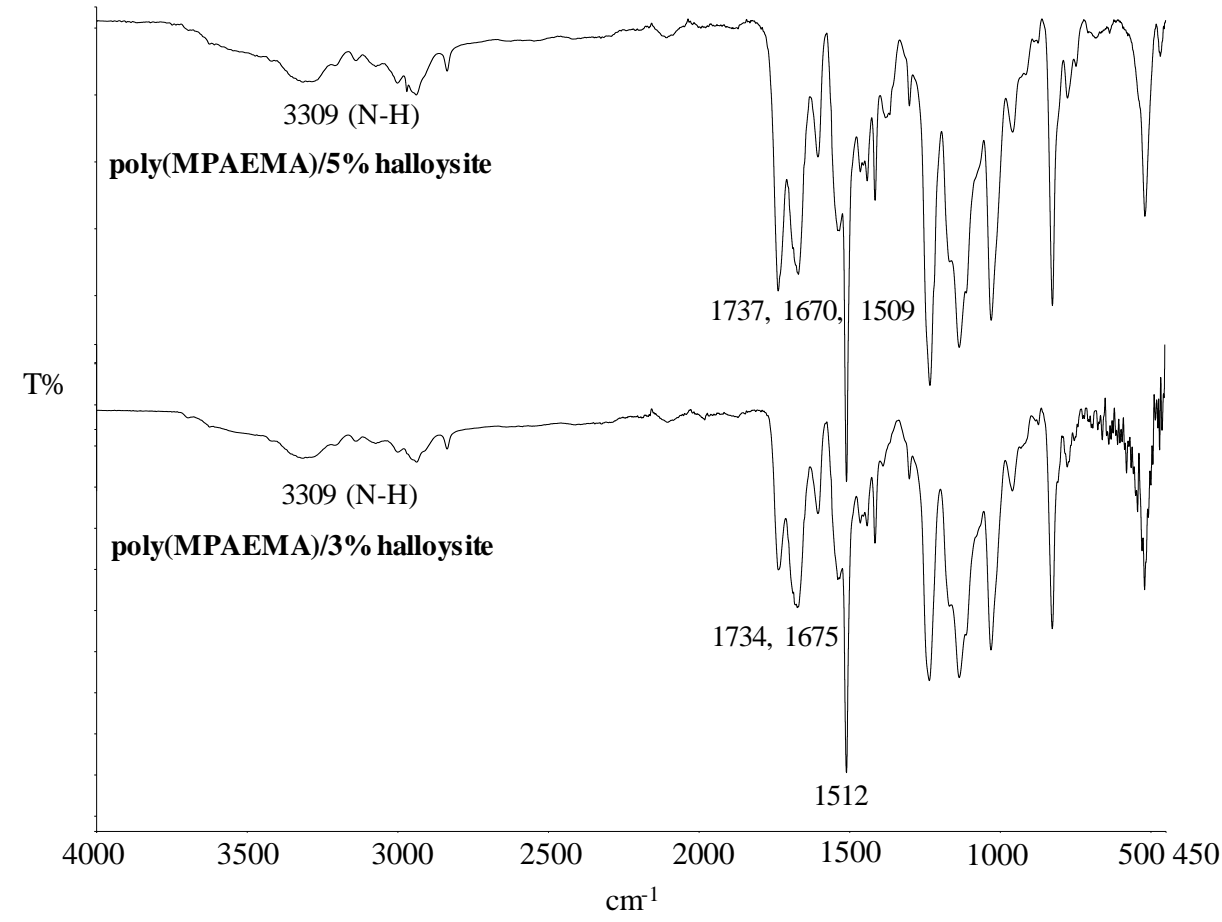

Fig. 5. FTIR spectra of poly(MPAEMA)/3\%halloysite and poly(MPAEMA)/5\%halloysite. 


\section{XRD measurements}

$\mathrm{X}$-ray diffraction is the preliminary technique to verify whether the layered structure has altered or not. In the literature, the characteristic crystalline peaks of halloysite clay is about $10 \mathrm{~A}^{\circ}[27,28]$. The XRD diffraction angle obtained from the Esan company for halloysite was read as $2 \theta=9^{\circ}, 20^{\circ}$. The distribution of the polymer between the layers of the clay causes a clear XRD peak in the nanocomposites to be unreadable. The absence of component-specific peaks in the composite materials can be explained by the fact that the polymer is intercalated between the clay layers, which become so irregular that they cannot give an XRD signal, $[1-3,26]$ therefore it can be considered as an exfoliated structure. Therefore, it can be considered as an exfoliated structure. Also, all peaks present in the XRD curve of the clays are not observed in the composites. The XRD patterns of the poly(MPAEMA)/halloysite nanocomposites are shown in Fig. 6.

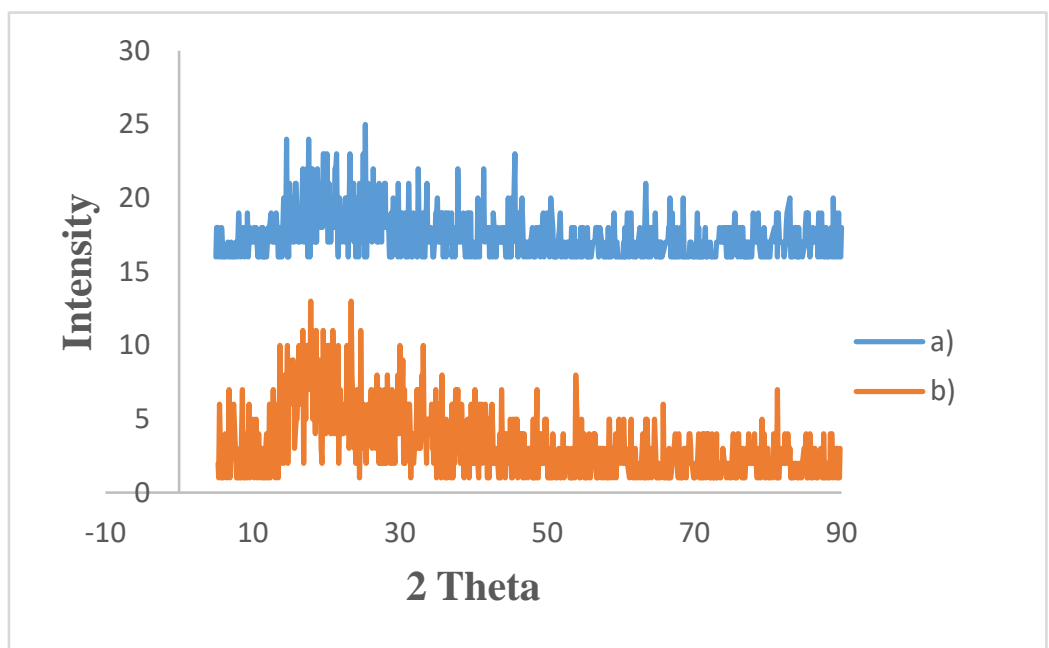

Fig. 6. XRD patterns of a) poly(MPAEMA)/3\%halloysite b) poly(MPAEMA)/5\%halloysite.

\section{Morphological study using SEM}

SEM technique was used to see the distribution of clay particles in polymer matrix in detail. The micrographs in Fig. 7 show the changes in morphology of the nanocomposites. The increase in the amount of clay resulted in particle size. SEM micrographs indicate that the polymer is dispersed into the clay layer, and clay has good compatibility and interfacial interaction with the homopolymer. The homogeneous distribution of the nanoparticles can be seen from the SEM photographs, and the particle sizes are close to each other. The clay is dispersed in the polymer matrix and this may show the exfoliated structure $[1,2,26]$.

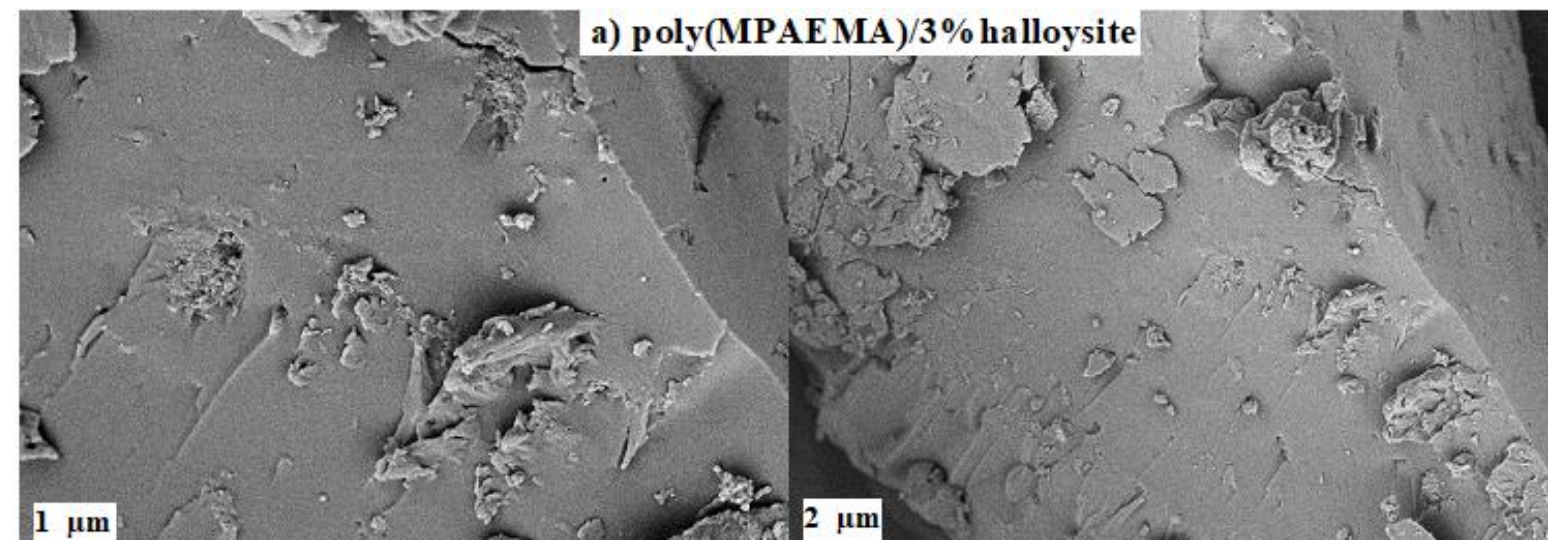




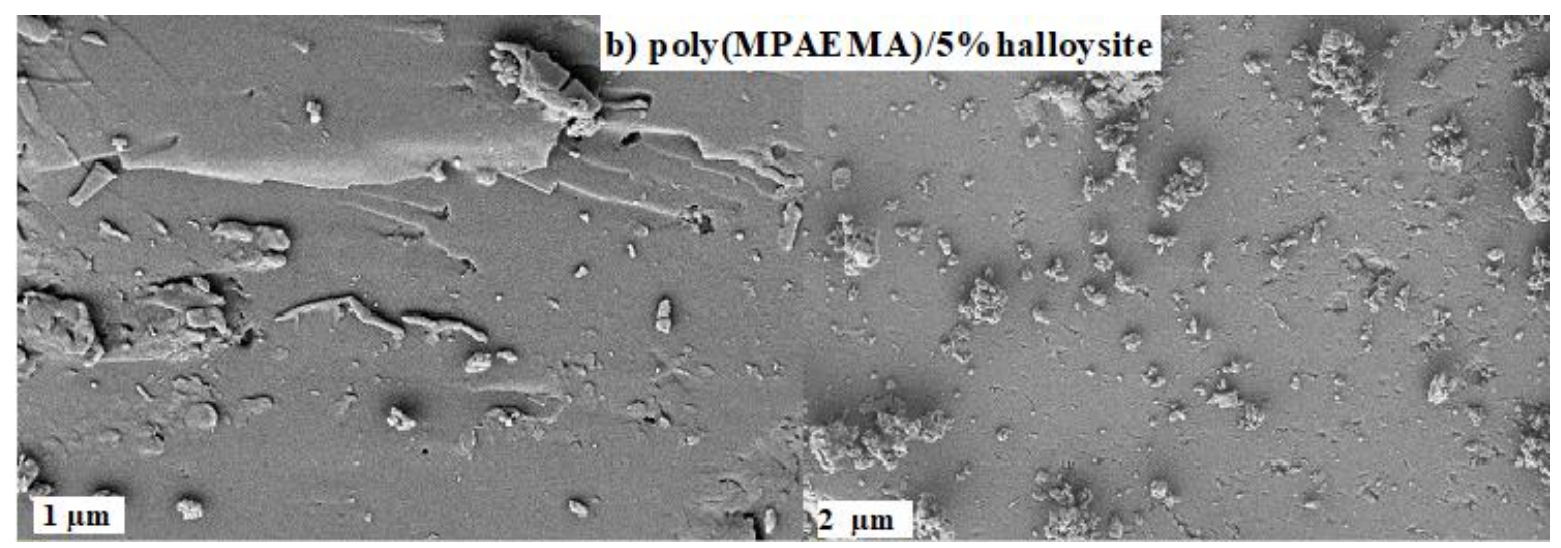

Fig. 7. SEM micrographs of a) poly(MPAEMA)/3\%halloysite b) poly(MPAEMA)/5\%halloysite.

\section{Thermal analysis using TGA/DTA/DTG}

Thermogravimetric analysis method helps determining the thermal stabilities of polymer/clay nanocomposites and provides information about their thermal behavior. The amount of clay in the composite affects the thermal stability and when the clay ratio in the composite increases, the residual ash ratio increases. When nanocomposites' thermal behaviors are compared, it is observed that composites containing clay have less mass loss percentage and partially better thermal stability with respect to homopolymer. It was observed that thermal stability of nanocomposites formed with clay increased with the increasing amount of clay in the composite, resulting in a clay thermal barrier. These thermal changes show that the polymer chains are distributed between clay galleries and the exfoliated composite is synthesized [1-3,26-30]. Thermogram obtained for nanocomposites are presented in Fig. 8 and Fig. 9, while some thermal data are given in Table 1.

Table 1. Some thermal data for poly(MPAEMA)/halloysite nanocomposites.

\begin{tabular}{|c|c|c|c|c|c|c|c|c|c|}
\hline 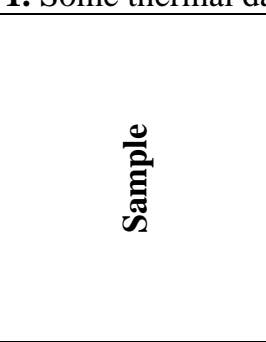 & 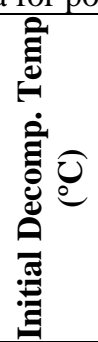 & 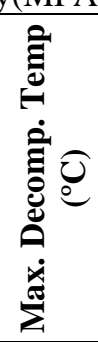 & 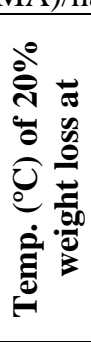 & 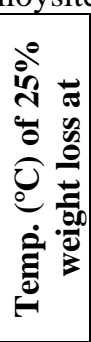 & 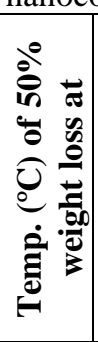 & 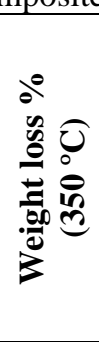 & 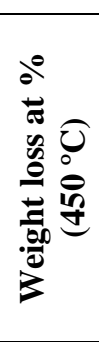 & 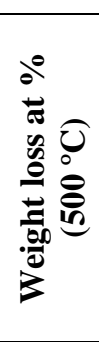 & 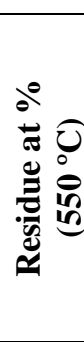 \\
\hline Halloysite & $\sim 232$ & 453 & - & - & - & 8 & 13 & 16 & 82 \\
\hline poly(MPAEMA) & $\sim 300$ & 360 & 341 & 349 & 370 & 26 & 90 & 94 & 5 \\
\hline $\begin{array}{c}\text { poly(MPAEMA) } \\
\text { /3\% halloysite }\end{array}$ & $\sim 316$ & 367 & 342 & 349 & 371 & 26 & 88 & 92 & 8 \\
\hline $\begin{array}{c}\text { poly(MPAEMA) } \\
/ 5 \% \text { halloysite }\end{array}$ & $\sim 315$ & 367 & 346 & 353 & 376 & 23 & 85 & 90 & 10 \\
\hline
\end{tabular}


a)

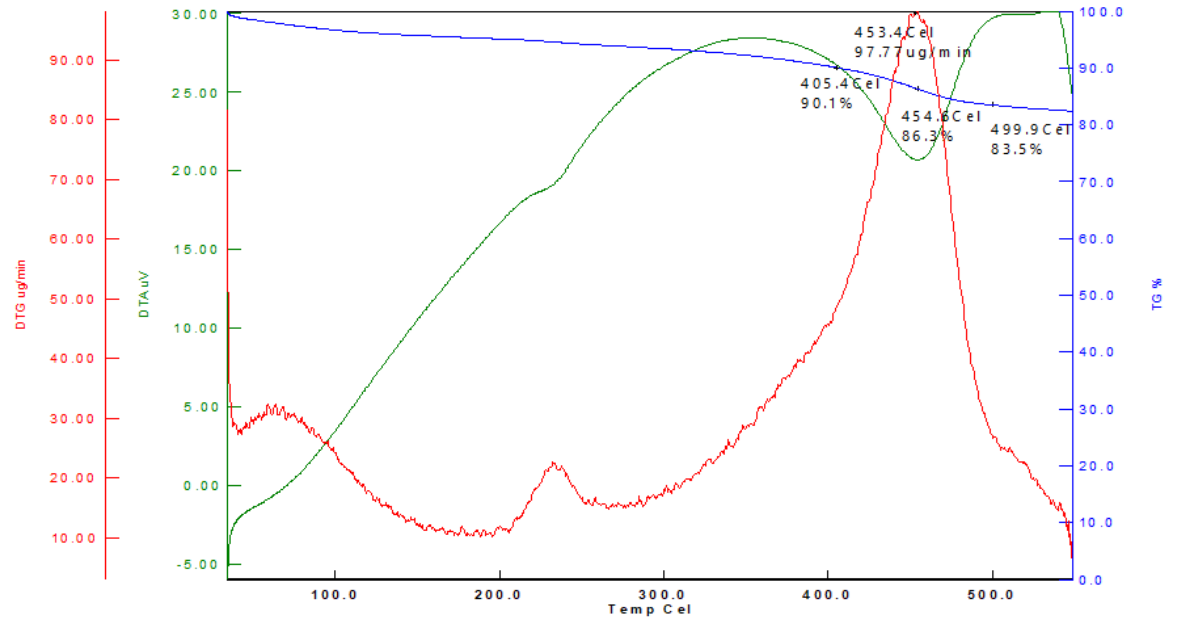

b)

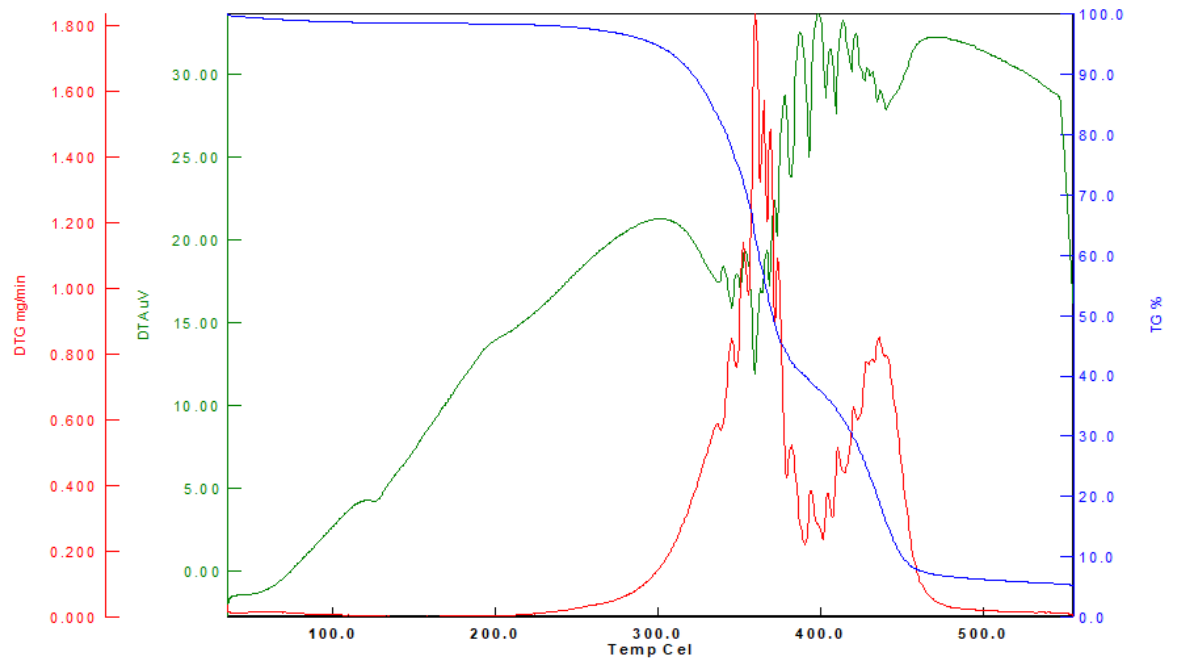

c)

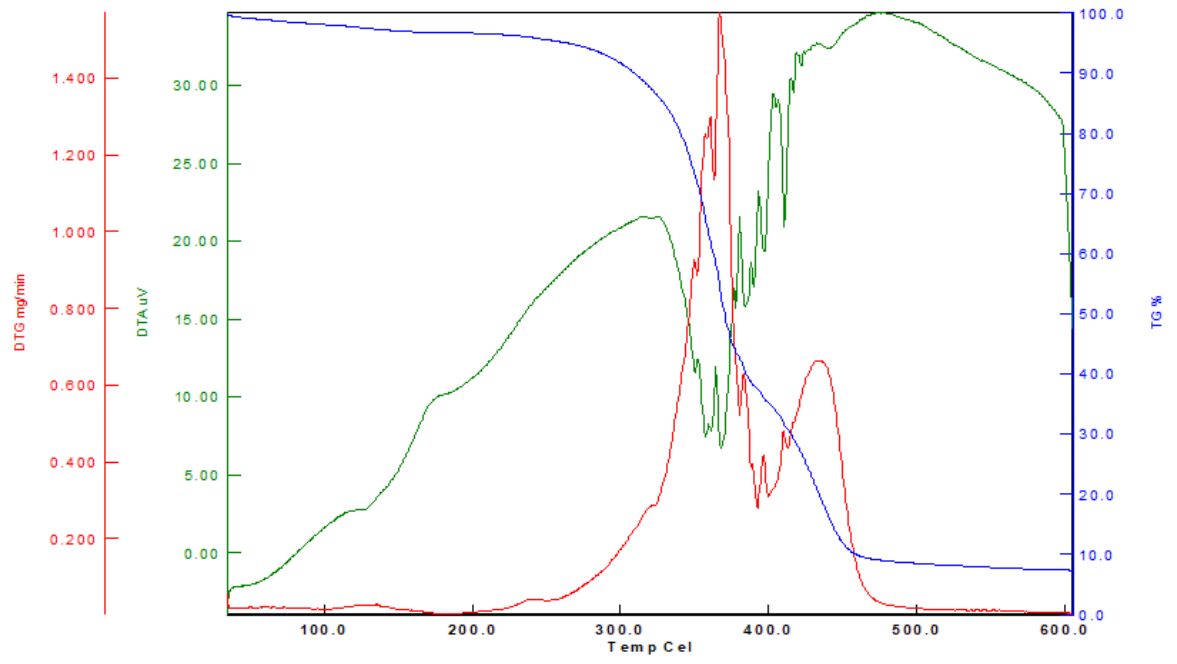


d)

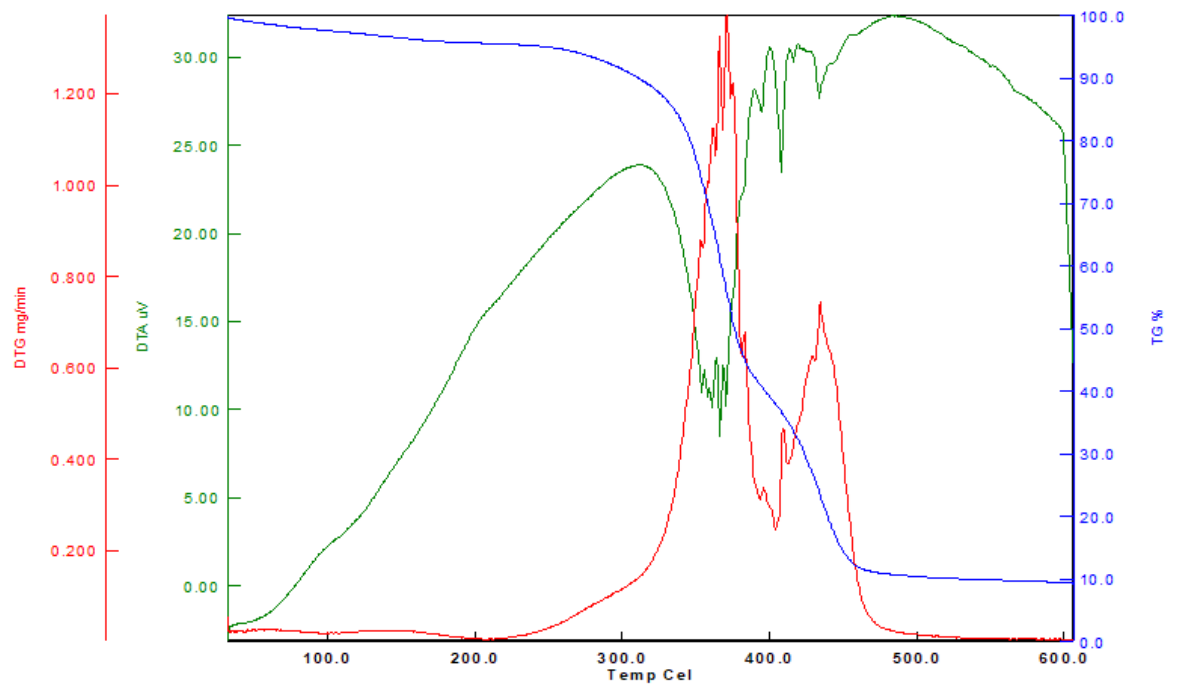

Fig. 8. The TGA/DTA/DTG curves of the a) Halloysite b) poly(MPAEMA) c) poly(MPAEMA)/3\%halloysite d) poly(MPAEMA) $/ 5 \%$ halloysite, respectively.

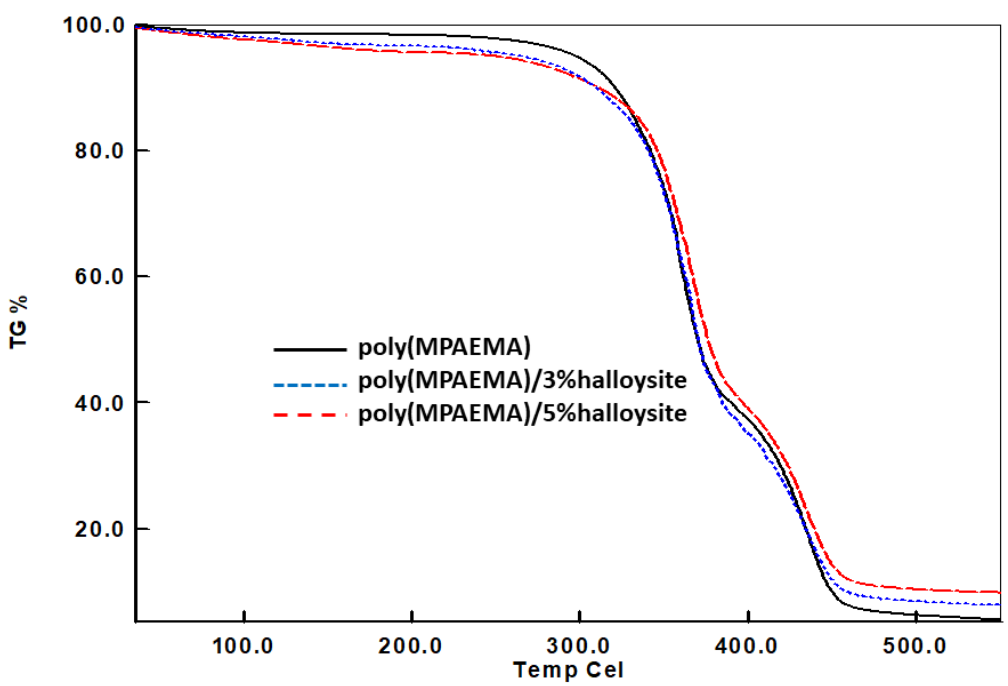

Fig. 9. Comparative TGA curves for MPAEMA homopolymer and its nanocomposites.

\section{Antiproliferative activity on HeLa cell line for halloysite, poly(MPAEMA), and their nanocomposites}

The cytotoxic effect on the halloysite, poly(MPAEMA), poly(MPAEMA)/3\%halloysite, poly(MPAEMA)/3\% halloysite was tested at the different concentration (up to $1000 \mu \mathrm{g} / \mathrm{mL}$ ) by the XTT assay (Fig. 10). Our findings demonstrated that poly(MPAEMA)/3\%halloysite, poly(MPAEMA)/5\%halloysite had no effect in inhibiting the proliferation of HeLa cells at $48 \mathrm{~h}$.

There are many studies on halloysite nanoclay in the literature. Halloysite is a preferred clay type because it is a natural material that cheap, available in abundance and has high mechanical strength. It also has potential uses in medicine, agriculture, cosmetics, and environmental improvement due to its non-toxicity 
properties [30-33]. Recently, the toxicity of halloysite nanoclay in vivo was reported, which showed that could induce some toxic effects on nematodes and the liver and lung of mice [34-37].

S-Fernández et al. investigated the biocompatibility and low cytotoxicity properties of functionalized halloysite by interacting halloysite with different organosilanes. The functionalized halloysite were tested using a WST-1 assay different concentrations $(100,250,500$, and $1000 \mu \mathrm{g} / \mathrm{mL})$ on HCT1 16 and HepG2 and especially highest concentration $(1000 \mu \mathrm{g} / \mathrm{mL})$ value exhibited decline in cellular viability [10,30-33,38-41]. Besides, in our study, by applying the nanocomposites up to a dose of $2000 \mu \mathrm{g} / \mathrm{mL}$, we showed that they have no toxic effect and can be used safely in agriculture, cosmetics, biomedical applications, as pharmaceutical and engineering materials etc. Similarly, we have demonstrated the toxic properties of the material. In contrast, the newly composites did not show any toxicity to cells. The non-toxic effect of the new nanocomposites may be due to the change in chemical groups.

The composite structures have not always increase toxic properties on in vitro and in vivo applications. Composites with reduced toxicity or non-toxic can be used for different purposes in medicine. For example, targeted delivery-based systems are one of the most prominent applications where gene, antibody, drug is administered to the desired location. Non-toxic carriers transport the drug-loaded/attached to them safely to the desired site. Studies suggest that carriers/materials have non-toxic properties [42].

Additionally, numerous studies have reported on halloysite clay in some cancer cell lines for e.g., HeLa, MCF-7, NIH-3T3, HepG2, HCT116 and A549 etc. [10,30-33,38-41]. In these studies, the safety of only halloysite nanocomposite has been reported against various cancer cell lines. Unlike these studies, in our study, the synthesis and characterization of raw halloysite, poly(MPAEMA)/3\%halloysite, poly(MPAEMA)/5\%halloysite and poly(MPAEMA) were performed, and their thermal and cytotoxic properties were investigated (Fig. 10).

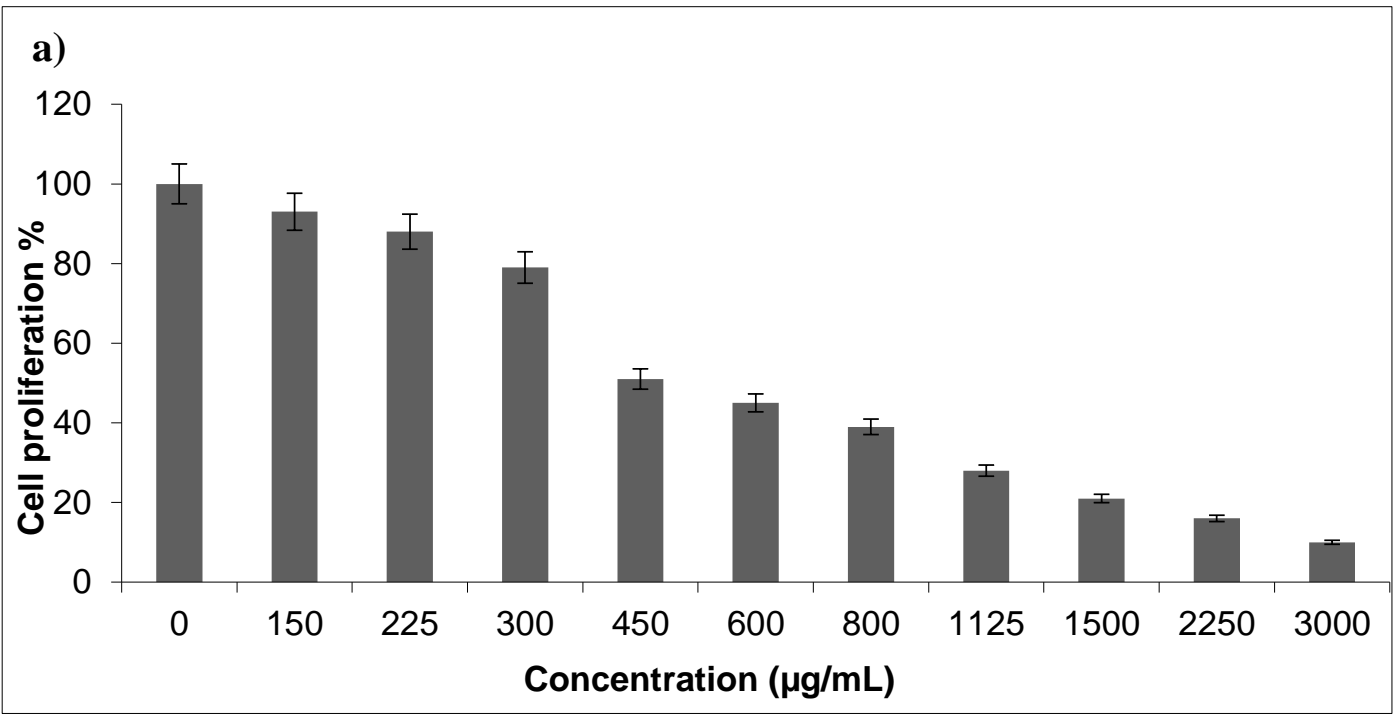



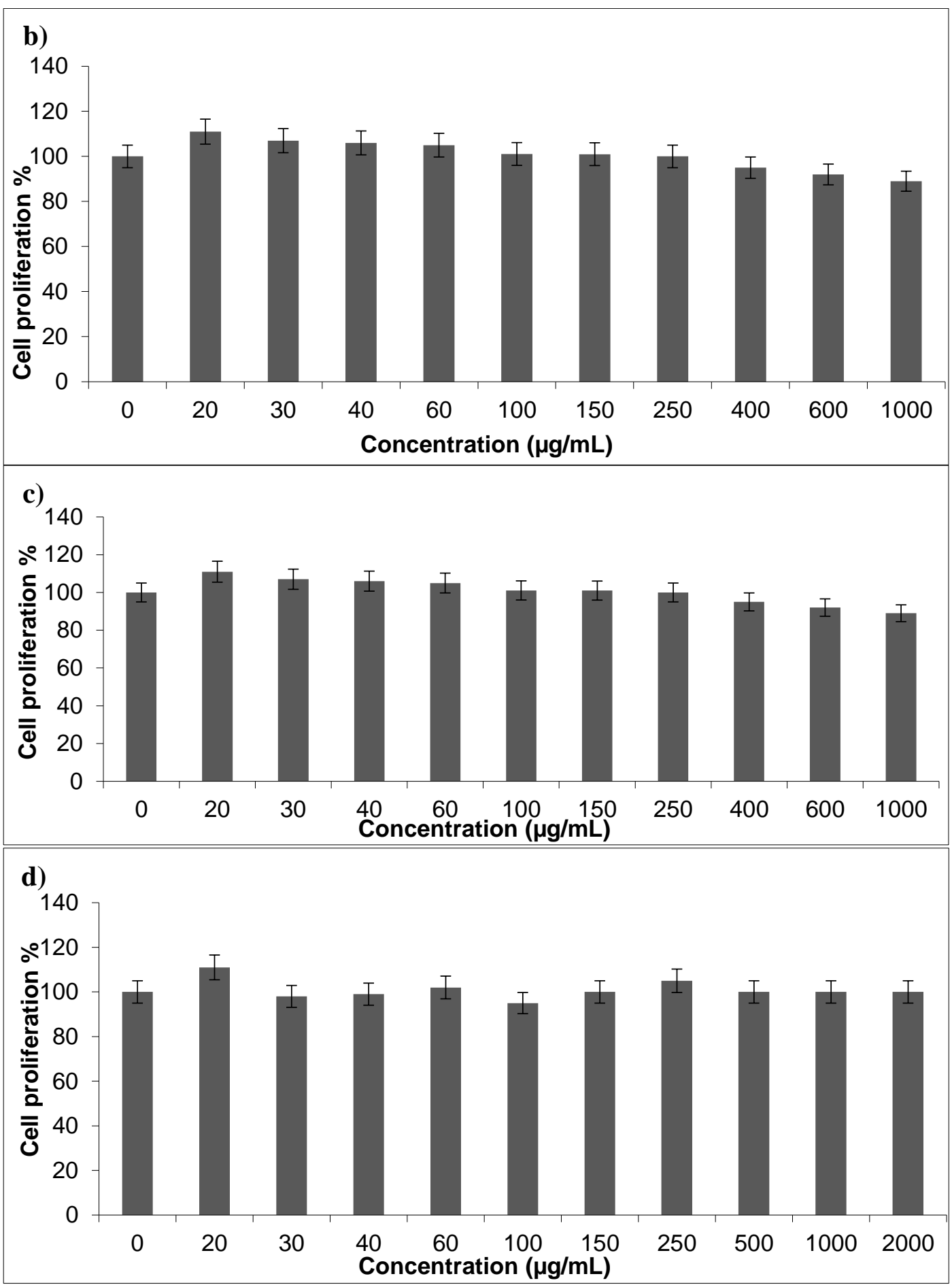

Fig. 10. Cytotoxicity analyses of a) halloysite clay b) poly(MPAEMA)/3\%halloysite poly(MPAEMA)/5\%halloysite d) poly(MPAEMA) on HeLa cells. 


\section{Conclusion}

In this study, for the first time in the literature, polymer/halloysite clay-based nanocomposites of poly(2-(4-methoxyphenylamino)-2-oxoethyl methacrylate) (MPAEMA) were synthesized by in-situ polymerization, and their thermal properties were investigated. FTIR, XRD, SEM, and TGA techniques were used at characterizations of nanomaterials. From XRD, SEM and thermal measurements, it was observed that the morphology of nanocomposites was exfoliated when the clay content in the polymer matrix was kept at $3 \%$ and $5 \%$. It was observed that the thermal stability of nanomaterials increased partially as the clay rate increased from thermal analysis. In addition, nanocomposites were not shown to have cytotoxic activity against HeLa cells and due to these properties, they may find applications in many research areas.

\section{Acknowledgement}

The authors would like to thank to Esan Eczacıbaşı for providing halloysite and Uşak University Research Fund for financial support of this work (2016/TP001 and 2014/ÖAP002).

\section{References}

1. Çankaya, N.; Şahin, R. Cell. Chem. Technol. 2019, 53, 537-549.

2. Kurt, A.; Topsoy O. K. Russ. J. Appl. Chem. 2017, 90, 2019-2027.

3. Kurt, A. and Yilmaz P. Kuwait J. Sci. 2016, 43, 172-184.

4. Bertolino, V.; Cavallaro, G.; Lazzara, G.; Merli, M.; Milioto, S.; Parisi, F.; Sciascia, L. Ind. Eng. Chem. Res. 2016, 55, 7373-7380.

5. Zhao, Y.; Zhang, B.; Zhang, X.; Wang, J.; Liu, J.; Chen, R. Water Sci. Technol. 2010, 62, 937-946.

6. Abdullayev, E.; Lvov, Y. J. Mater. Chem. 2010, 20, 6681-6687.

7. Luo, P.; Zhang, J.; Zhang, B.; Wang, J. H.; Zhao, Y. F.; Liu, J. D. Ind. Eng. Chem. Res. 2011, 50, 10246-10252.

8. Zhao, Y.; Zhang, B.; Zhang, X.; Wang, J.; Liu, J.; Chen, R. J. Hazard. Mater. 2010, 178, 658-664.

9. Luo, P.; Zhao, Y.; Zhang, B.; Liu, J.; Yang, Y.; Liu, J. Water. Res. 2010, 44, 1489-1497.

10. Vergaro, V.; Abdullayev, E.; Lvov, Y. M.; Zeitoun, A.; Cingolani, R.; Rinaldi, R.; Leporatti, S. Biomacromolecules 2010, 11, 820-826.

11. Sanchez-Fernández, A.; Pena-Paras, L.; Vidaltamayo, R.; Cue-Sampedro, R.; Mendoza-Martínez, A.; Zomosa-Signoret, V. C.; Rivas-Estilla, A. M.; Riojas, P. Materials 2014, 7, 7770-7780.

12. Lvov, Y.; Abdullayev, E. Prog. Polym. Sci. 2013, 38, 1690-1719.

13. Price, R.; Gaber, B.; Lvov, Y. J. Microencapsul. 2001, 18, 713-723.

14. Kelly, H.; Deasy, P.; Ziaka, E.; Claffey, N. Int. J. Pharm. 2004, 274, 167-183.

15. Levis, S.; Deasy, P. Int. J. Pharm. 2002, 243, 125-134.

16. Shchukin, D.; Price, R.; Sukhorukov, G.; Lvov, Y. Small 2005, 5, 510-513.

17. Kamble, R.; Ghag, M.; Gaikawad, S.; Panda, B.K. J. Adv. Sci. Res. 2012, 3, 25-29.

18. Tanış, E.; Çankaya, N.; Yalçın, S. Chin. J. Phys. 2019, 57, 348-361.

19. Kakade, D. P.; Arora S.; Ambwani, S. Res. J. Biotechnol. 2018, 13, 68-74.

20. Çankaya, N.; Besci, G. J. Fac. Eng. Arch. Gazi 2018, 33,1155-1170.

21. Çankaya, N. ITJEMAST 2020, 11, 1-8.

22. Acikbas, Y.; Cankaya, N.; Capan, R.; Erdogan, M.; Soykan, C. J. Macromol. Sci. A 2016, 53, 18-25.

23. Daşbaşı, T.; Soykan, C.; Çankaya, N.; Ülgen, A. J. Macromol. Sci. A 2018, 55, 466-473. 
24. Kloprogge, J. T. Dev. Clay Sci. 2016, 7, 115-136.

25. Gaaz, T.S. Molecules 2017, 22, 838.

26. Delibas, A.; Alparslan, M. Turk J. Chem. 2015, 39, 630-638.

27. Chenga, H.; Liua, Q.; Yangc, J.; Zhang, J.; Frost, R. L. Thermochim. Acta 2010, 511, 124-128.

28. Bac, B. H.; Dung, N. T. Vietnam J. Earth Sci. 2015, 37, 299-306.

29. Shi, Y.; Tian, Z.; Zhang, Y.; Shen, H. and Jia, N. Nanoscale Res. Lett. 2011, 6, 1-7.

30. Pasbakhsh, P.; Churchman, G. J.; Keeling, J. L. Appl. Clay Sci. 2013, 74, 47-57.

31. Churchman, G. J.; Pasbakhsh, P. Current trends in research and application of natural mineral nanotubes in: Natural Mineral Nanotubes (Pasbakhsh P. and Churchman G.J., editors). Apple Academic Press, Oakville, Canada, 2015, 481-488. 10.1201/b18107-37

32. Yuan, P.; Tan, D.; Annabi-Bergaya, F. Appl. Clay Sci. 2015, 112-113, 75-93.

33. Hanif, M.; Jabbar, F.; Sharif, S.; Abbas, G.; Farooq, A.; Aziz, M. Clay Miner. 2016, 51, 469-477.

34. Fakhrullina, G. I.; Akhatova, F. S.; Lvov, Y. M.; Fakhrullin, R. F. Environ. Sci. Nano 2015, 2, 54-59. 35. Wang, X.; Gong, J.; Gui, Z.; Hu, T. and Xu, X. Environ. Toxicol. 2018, 33, 623-630.

36. Wang, X.; Gong, J.; Rong, R.; Gui, Z.; Hu, T.; Xu, X. J. Agric. Food Chem. 2018, 66, 2925-2933.

37. Long, Z.; Wu, Y.; Gao, H.; Zhang, J.; Ou, X.; He, R.; Liu, M. J. Mater. Chem. B. 2018, 6, 7204-7216.

38. Maisanaba, S.; Pichardo, S.; Puerto, M.; Gutiérrez-Praena, D.; Cameán, A. M.; Jos, A. Environ. Res. 2015, 138, 233-254.

39. Suh, Y. J.; Kil, D. S.; Chung, K. S.; Abdullayev, E.; Lvov, Y. M.; Mongayt, D. J. Nanosci. Nanotechnol. 2011, 11, 661-665.

40. Verma, N.; Moore, E.; Blau, W.; Volkov, Y.; Ramesh Babu, P. J. Nanopart. Res. 2012, 14, 1-11.

41. Ahmed, F. R.; Shoaib, M. H.; Azhar, M.; Um, S. H.; Yousuf, R. I.; Hashmi, S.; Dar, A. Colloid Surf. $B$ 2015, 135, 50-55.

42. Ali, Y.; Alqudah, A.; Ahmad, S.; Hamid, S. A.; Farooq, U. Des. Monomers Polym. 2019, 22, 91-97. 